\title{
THE INFLUENCE OF INFORMATION ACCESS, KNOWLEDGE, PERCEPTION OF FAMILY PLANNING'S RISKS, AND HUSBAND'S SUPPORT ON INTEREST OF USING CONTRACEPTION FOR UNMET NEED GROUP
}

\author{
Lilik Noor Yuliati $^{\left.{ }^{*}\right)}$, Megawati Simanjuntak ${ }^{1}$, Oktriyanto $^{2}$ \\ ${ }^{1}$ Family and Consumer Sciences Department, IPB University, Bogor 16680, Indonesia \\ ${ }^{2}$ National Population and Family Planning Board (BKKBN), Jl. Permata 1 No.1 Jl. Halim Perdanakusuma, \\ RT.4/RW.5, Kb. Pala, Makasar, Kota Jakarta Timur, Daerah Khusus Ibukota Jakarta, 13650, Indonesia \\ "E-mail: lilikny@apps.ipb.ac.id
}

\begin{abstract}
This study aims are to analyze the influence of information access, knowledge, perception of contraception for birth control risk, and husband's support on unmet need group's interest in using contraception. This research used a cross-sectional study design and survey method. The research was conducted in Bogor City, Indonesia with 200 respondents (wives). Data was collected through face-to-face interview. Data were analyzed descriptively and inferred using Structural Equation Modelling (SEM). The respondents were selected purposively. Based on research's result, the wife's knowledge regarding contraception using was in the medium category. However, knowledge about contraception devices was still in the low category. In this research, wives perceive that family planning has little risk for health and non-health. Husband's support was categorized as good and the husbands allowed their wife to use contraception but did not get involved in the decision-making. The respondents had reasonably good interest in contraception using by considering 6 to 10 respondents prefer not to use contraception. Research result showed the accepted hypothesis are access to information influences knowledge $(\mathrm{H} 1)$, perceived risk influences interest $(\mathrm{H} 5)$, access to information does not influences risk perception (H2), knowledge does not influence risk perception (H3), knowledge has no effect on interest $(\mathrm{H} 4)$, so does husband's support (H6).
\end{abstract}

Keywords: husband support, information access, interest of FP, knowledge, perception of risk

\section{Pengaruh Akses Informasi, Pengetahuan, Persepsi Risiko Ber-KB, dan Dukungan Suami terhadap Minat Ber-KB pada Kelompok Unmet Need}

\begin{abstract}
Abstrak
Penelitian ini bertujuan untuk menganalisis pengaruh akses informasi, pengetahuan, persepsi risiko Keluarga Berencana (KB), dan dukungan suami terhadap minat menggunakan alat kontrasepsi pada kelompok Unmet Need. Penelitian ini menggunakan desain penelitian cross-sectional dan metode survei. Penelitian ini dilakukan di Kota Bogor, Indonesia dengan 200 responden (istri). Data dikumpulkan melalui wawancara tatap muka. Data dianalisis secara deskriptif dan inferensia dengan menggunakan Structural Equation Modeling (SEM). Responden dipilih secara sengaja. Berdasarkan hasil penelitian, pengetahuan istri pada kelompok Unmet Need tentang KB ditemukan dalam kategori sedang, tetapi pengetahuan tentang alat kontrasepsi masih dalam kategori rendah. Dalam penelitian ini, istri berpersepsi bahwa ber-KB memiliki sedikit risiko bagi kesehatan maupun nonkesehatan Dukungan suami dikategorikan baik dan para suami mengizinkan istri mereka menggunakan KB tetapi tidak terlibat untuk mengambil keputusan. Minat istri untuk menggunakan KB cukup baik yang ditunjukkan dari enam hingga sepuluh responden memilih untuk tidak menggunakan alat kontrasepsi. Penelitian menunjukkan hipotesis yang diterima dengan baik adalah akses informasi mempengaruhi pengetahuan ( $\mathrm{H} 1)$, persepsi risiko mempengaruhi minat (H5), akses informasi tidak berpengaruh terhadap persepsi risiko (H2), pengetahuan tidak berpengaruh terhadap persepsi risiko $(\mathrm{H} 3)$, pengetahuan tidak berpengaruh terhadap minat $(\mathrm{H} 4)$, demikian pula dengan dukungan suami $(\mathrm{H} 6)$.
\end{abstract}

Kata kunci: akses informasi, dukungan suami, minat KB, pengetahuan, persepsi risiko

\section{INTRODUCTION}

One of the government programs to prevent excessive childbirth is Family Planning (FP). FP program was initiated by the government using two methods, namely contraception service and also communication, information, and education service (Komunikasi, Informasi, dan Edukasil KIE)). National Family Planning Coordinating Agency $(B K K B M)$ enacted to manifest population and Family Planning (FP) goals in the National Medium Term 
Development Plan (Rencana Pembangunan Jangka Menengah Nasional/RPJMM in 20152019 , with the aim is to reduce the total birth rate from 2.6 to 2.28 children per woman, increasing the use of contraception devices (Contraceptive Prevalence Rate/CPR) from 61.9 to 66.0 percent, and reduce the unmet need from 11.4 to 9.91 percent in 2019 (www.bkkbn.go.id).

Unmet need for FP is one of the problems in Indonesia. Unmet need is a group whose contraceptive needs have not been met yet, including fertile age men and women who are married or living together and sexually active, who do not use contraceptive methods, either because they do not want to have more children or to delay the next birth. This unmet need namely thinning group when the fertile age partner is not pregnant and does not use contraception and only want to have children later in two years or more, or the one who gets pregnant whose pregnancy is desired later ( 2 years or more). The unmet need namely birth control group is defined as the case of the reproductive age is not pregnant and not use contraception because does not want another child or is in a state of unwanted pregnancy. In 2017, the unmet need group in Indonesia was 17.5 percent which is consisted of 8.2 percent of thinning and 9.3 percent of birth control. These results have not yet achieved the national target, which was set at 10.26 percent. The high number of unmet need is one of the reasons for the Total Birth Rate (TFR) to increase from the 2.34 in to 2.4 in 2017 . This has not yet reached the 2017 national target of 2.33 women. In 2017, Total Fertility Rate (TFR) of Indonesia was $2.4 \mathrm{n}$, which means that an average woman in Indonesia gives birth to 2.,4 children during her reproductive period in 2016-2017. However, the number of unmet need for FP varies by province. High unmet need areas in Indonesia are spread in ten provinces that are Jambi, Central Java, West Java, East Java, South Sumatra, South Sulawesi, North Sulawesi, East Nusa Tenggara, East Kalimantan, and the Special Region of Yogyakarta. The number of unmet need in West Java is quite high, reaching 14.4 percent, consist of 4.3 percent of thinning and 10.1 percent of restrictions. This implies that unmet need in West Java is still higher compared to the national target of 10.26 percent.

The achievement of active FP participants in Bogor City Population and Family Planning Control Office in June 2018 stated the amount of unmet need in Bogor City was 23.188. In
Bogor City, there were two sub-districts with high unmet need, namely West Bogor Subdistrict of 6,515 and South Bogor Sub-District with 5.390. The numbers of unmet needin birth control services was higher in the cities compared to rural areas (19.4 and 16.3 percent).

Therefore it is intriguing to study unmet need group interest in birth control, especially in urban area. Family planning is an attempt to outline or plan the number and distance of pregnancy using contraception, in order to create a small, happy and prosperous family (BKKBN 2008). The demographic characteristics, socio-economic, attitudes, and access to services could affect unmet need for family planning. Unmet need for family planning occurs among women who have some barriers such as financial, educational, geographical, and social. Unmet need for family planning is higher among women who are highly educated and who are not in school compared to women in other education groups. The results of the Indonesian Demographic and Health Survey (Survei Demografi dan Kependudukan Indonesia/SDKI) showed an increasing prevalence of injecting contraception for birth control users (Wijaya, Aminah \& Ristanto, 2013). The previous research have been confirmed that interest is influenced by access to information, knowledge, and perception of contraception for birth control risks.

Some information that had been spread by media to increase knowledge is called information access (Rehman, Javed, Nawaz, Ahmed, \& Hyder, 2014). Information access that has been received by couples of reproductive age (Pasangan Usia Subur/PUS), women of reproductive age (Wanita Usia Subur(WUS), adolescents, and family in according to the performance of the Population, Family Planning and Family Development Kependudukan, Keluarga Berencana, dan Pembangunan Keluarga/KKBPK) program through mass media (print, electronic), outdoor media (poster, leaflets, flipcharts, banners), and traditional media were still low (BKKBN 2017 Survey). The exposure of information and FP messages through mass media can increase contraceptive use by 80 percent. Most of them (over $50 \%$ ) have axposured contraception message and information from the media 4 to 6 times.

Previous finding confirmed subjective knowledge affects negative risk perceptions 
(Koklic, 2011). Other research suggests that there is a significant relationship between knowledge and wife's perception of using contraception. The knowledge about contraception was not related to risk perception (Putri \& Simanjuntak 2012). Perception of contraception users concerning the quality of service has a huge contribution in intensifying interest and participation of FP programs (Sudarti \& Prasetyaningtyas, 2011). The results discovered that husband's support has a significant influence on the occurrence of unmet need (Nanlohy, 2017). The proportion of couples of reproductive age who have knowledge and understanding of all types of modern contraceptive methods were still low that is amounting to 17.2 percent which has not yet achieved the target of National Strategic Plan 2017 that is 30 percent. Meanwhile, in 2017, knowledge of couples of reproductive age about eight modern contraceptive methods in West Java was 21.53 percent (Bappenas 2017 Survey).

the aims of this study were: (1) to identify access to information, knowledge, perceptions of contraception for birth control's risks, husband's support, and interest of contraception for birth control in unmet need groups; (2) to analyze the influence of access to information, knowledge, perceptions of contraception for birth control risks, and husband's support interest of contraception for birth control in unmet need groups; and (3) to formulate policy implications in order to reduce unmet need for FP program. This study has a high urgency to implement because it is in line with policies and strategies of National Family Planning Coordinating Agency (BKKBN) that have a focus on: (1) increasing access and quality of FP services; (2) strengthening the advocacy and communication, information, and education service (Komunikasi, Informasi, dan Edukasil KIE) of Population, Family Planning and Family Development (Kependudukan, Keluarga Berencana, dan Pembangunan Keluarga/KKBPK) program; (3) reducing the number of unmet need group for FP. The output of this study could be used as a basis reference for stakeholders to develop a model of strategic solutions in the form of population, family planning, and family development program that will be implemented with a focus on reducing the number of unmet need for FP.

\section{METHODS}

This research was held using a cross-sectional study with survey method. The research was conducted in Bogor City particularly in
Cilendek Timur and Pasir Kuda urban communities for West Bogor Sub-District, while South Bogor Sub-District were represented by Bondongan and Cipaku urban communities. The urban communities was chosen based on the consideration that the number of unmet needs group was greater than in rural areas (BKKBN 2017 Survey). Furthermore, the selection of sub-districts and urban communities were carried out by analyzing the highest number of unmet need group in Bogor City. The amount of unmet need group in West Bogor Sub-District was 6,515 people while in South Bogor Sub-District is 5,390 people.

The participants of this study were family with reproductive age and unmet need group in both sub-district. The amount of participant were 200 people in total and selected by purposive. Data were collected using direct interview technique by questionnaires that had been tested prior for their reliability and validity.

Access to information is defined as sources of information regarding contraception for birth control that is obtained by respondents from mass media and FP officers. In this study, access to information is divided into two dimensional, which are information from the mass media and FP officers. Access to information's instrument refers to BKKBN 2017 Survey.

Knowledge is defined as how much information of the respondent has already including general knowledge about contraception for birth control, FP equipment, and contraception for birth control distribution of contraception devices. The knowledge variable is divided into three major parts, namely: general knowledge, knowledge about contraception for birth control equipment, and knowledge of the distribution of contraception devices. The knowledge's instrument refers to Farahan (2016) that has value of the reliability was 0.717 . The scale that was used to measure the knowledge variable was "I know" and "I don't know".

Risks perception is defined as negative views about contraception related to health and nonhealth (money, time) risks. Risks perception consists of two dimensions which are health and non-health. Risk perceptions' instrument was adapted from Putri and Simanjuntak (2013) for risk perception. Reliability value of risk perception was 0.715 . The scale that was used to measure risks perception variable was the Likert scale which is categorized as "STS = Strongly Disagree", "TS $=$ Disagree", "KS = 
Disagree", "S = Agree", and "SS = Strongly Agree".

Husband's support is defined as the involvement of husband in choosing and using contraception and also accessing family planning services. Husband's support instrument refers to Nanlohy (2017) for husband's support. The value of the reliability of husband's support instrument was 0.665. The scale that was used to measure the husband's support variable was "Yes" and "No"

Interest is defined as the tendency of one's heart to be high towards the desire to use contraception for birth control. It is closely related to conscience. Interest variable had only one statement. The instrument was adapted from Susilawati (2013) for interest and reliability value of interest was 0,958 . The scale used to measure the interest was "Yes" and "No".

The collected data were processed and analyzed using Microsoft Excel, Statistical Package for Social Science (SPSS), and Analysis of Moment Structures (AMOS). Data analysis was done by descriptive and inferred using Structural Equation Modelling (SEM). Descriptive analysis was used to determine the values of minimum, maximum, average and standard deviation of sample characteristics, access to information, knowledge, perceptions of contraception for birth control risks,

Table 1 Distribution of respondents' characteristic

\begin{tabular}{|c|c|c|c|c|}
\hline \multirow{2}{*}{ Characteristics/Categories } & \multicolumn{2}{|r|}{ Wife } & \multicolumn{2}{|r|}{ Husband } \\
\hline & Total $(n)$ & Percentage (\%) & Total $(n)$ & Percentage (\%) \\
\hline \multicolumn{5}{|l|}{ Age (years) } \\
\hline - $15-19$ & 2 & 1.0 & 0 & 0.0 \\
\hline - $20-24$ & 16 & 8.0 & 2 & 1.0 \\
\hline - $25-29$ & 35 & 17.5 & 17 & 8.5 \\
\hline - $30-34$ & 40 & 20.0 & 38 & 19.0 \\
\hline - $35-39$ & 41 & 20.5 & 46 & 23.0 \\
\hline - $40-44$ & 38 & 19.0 & 34 & 17.0 \\
\hline - $45-49$ & 28 & 14.0 & 36 & 18.0 \\
\hline - $>49$ & 0 & 0.0 & 27 & 13.5 \\
\hline \multicolumn{5}{|l|}{ Education's duration (years) } \\
\hline - $0-6$ & 55 & 27.5 & 46 & 4.0 \\
\hline - 7-9 & 60 & 30.0 & 48 & 24.0 \\
\hline - $10-12$ & 77 & 38.5 & 97 & 48.5 \\
\hline - $13-16$ & 8 & 4.0 & 9 & 4.5 \\
\hline \multicolumn{5}{|l|}{ Occupation } \\
\hline - Unemployed & 167 & 83.5 & 3 & 1.5 \\
\hline - Entrepreneur & 13 & 6.5 & 31 & 15.5 \\
\hline - PNS/TNI/Polri & 0 & 0 & 10 & 5.0 \\
\hline
\end{tabular}

husband's support, and interest of unmet need group. The inferential analysis used in this study was Structural Equation Modeling (SEM). Descriptive analysis was also used to comprehend the relationship between variables (respondent characteristics, access to information, knowledge, perceptions of contraception for birth control risks, husband's support, and interests). The total score of each variable was indexed into a scale of $0-100$ using the following formula. The index results of the variables were categorized into three categories, namely the low category for index score of $00,0-60,0$; the index score for the medium category is 60-80; and index score of $80,0-100,0$ for the high category (Sunarti, Tati., Nuraini, Noorhaisma, Lembayung, 2005).

$$
\text { Index }=\frac{\text { actual score-minimum score }}{\text { maximum score-minimum score }} \times 100
$$

\section{RESULTS}

Based on reproductive age criteria, the age of respondents has range from 15 until $>49$ years old. The result shows that the highest proportion of respondents are 35-39 years old. This reflects that respondents are still classified as fertile age couples (EFA). In this study, almost half of the respondents' husband have education level for 10-12 years, as well as the education level of the respondents $(38.5 \%)$. It also shows that only a few husbands (4.5\%) and respondents/wife (4.0\%) studied for 13-16 years. 
(Advanced) Table 1 Distribution of respondents' characteristic

\begin{tabular}{|c|c|c|c|c|}
\hline \multirow[t]{2}{*}{ Characteristics/Categories } & \multicolumn{2}{|c|}{ Wife } & \multicolumn{2}{|c|}{ Husband } \\
\hline & Total $(n)$ & Percentage (\%) & Total $(n)$ & Percentage (\%) \\
\hline - $\quad$ Private employee & 8 & 4 & 42 & 21.0 \\
\hline - Laborer & 11 & 5.5 & 108 & 54.0 \\
\hline - Others* & 1 & 0.5 & 6 & 3.0 \\
\hline \multicolumn{5}{|l|}{ Income per capita } \\
\hline - $\quad \geq \operatorname{Rp} 401.220$ & & & 154 & 77.0 \\
\hline - $\quad<\operatorname{Rp} 401.220$ & & & 46 & 23.0 \\
\hline \multicolumn{5}{|l|}{ Duration of Marriages } \\
\hline - $0-5$ years & & & 38 & 19.0 \\
\hline - 6-10 years & & & 58 & 29.0 \\
\hline - $11-15$ years & & & 42 & 21.0 \\
\hline - $16-20$ years & & & 24 & 12.0 \\
\hline - $\quad>20$ years & & & 38 & 19.0 \\
\hline \multicolumn{5}{|l|}{ Losing Pregnancy } \\
\hline - $\quad$ Never & & & 156 & 78.0 \\
\hline - Ever & & & 44 & 22.0 \\
\hline \multicolumn{5}{|l|}{ Number of Children } \\
\hline - $\leq$ Two persons & & & 148 & 74.0 \\
\hline - $\quad>2$ persons & & & 52 & 26.0 \\
\hline \multicolumn{5}{|l|}{ Desired Number of Children } \\
\hline - Equal & & & 136 & 68.0 \\
\hline - Husbands prefer more & & & 46 & 23.0 \\
\hline - Husbands prefer fewer & & & 18 & 9.0 \\
\hline
\end{tabular}

The results (Table 1) shows that the highest length of marriage in this study is in the range of $6-10$ years $(29.0 \%)$. In this study, over one of five respondents had experienced a history of pregnancy loss and nearly three quarter of respondents have children less than or equal to two children, and the other have more than two children (26.0\%). According to this study, 68.0 percent of husbands and wives wanted the same number of children. It is showed by nearly one of four of husband want more children than wives, and only a few husbands $(9.0 \%)$ want fewer children than their wives. Meanwhile, according to family income, it is showed that 23.0 percent families were classified as poor because they earn less than Rp401,220. Most of the respondents (77.0\%) have family who earned more than or equal to Rp401,220 categorized by the Central Statistics Agency (BPS) in March 2018.

\section{Access to Information}

Table 2 shows the majority of the respondents $(94.0 \%)$ had access to information related to contraception for birth control and FP program and only a few of them (6.0\%) did not have access to information about FP. The average information access variable was also high which means that respondents have received quite a lot of information regarding FP. Respondents were exposed to information about contraception for birth control and FP program through mass media. Specifically, television $(87.0 \%)$, and very few $(1.0 \%)$ were exposed through newspapers. The officer who provides the majority information about contraception for birth control and FP program to respondents was midwives or nurses $(60.5 \%)$.

\section{Knowledge}

According to the knowledge of respondents about contraception for birth control and FP program, the result that is shown in Table 2 revealed that almost half of respondents had general knowledge about contraception for birth control and FP program that was categorized as medium (57.0\%) and high $(16.5 \%)$, and only 26.5 percent were categorized as low. 
Table 2 Distribution of respondents based on the research variables and its values of minimum, maximum, meand, and standar deviation

\begin{tabular}{lrrrrr}
\hline \multirow{2}{*}{ Categories } & \multicolumn{5}{c}{ Variables } \\
\cline { 2 - 6 } & $\begin{array}{c}\text { Access to } \\
\text { Information (\%) }\end{array}$ & Knowledge (\%) & $\begin{array}{c}\text { Perception of } \\
\text { Risks (\%) }\end{array}$ & $\begin{array}{c}\text { Husband's } \\
\text { Support (\%) }\end{array}$ & Interest (\%) \\
\hline Low (00.0-60.0) & 6.0 & 26.5 & 76.5 & 28.0 & 39.0 \\
Medium (60.1-80.0) & 0.0 & 57.0 & 23.0 & 43.5 & 0 \\
High (80.1-100.0) & 94.0 & 16.5 & 5.0 & 28.5 & 61.0 \\
\hline Min-Max & $0.0-100.0$ & $11.1-100.0$ & $29.6-82.8$ & $17.0-100$ & $0-100$ \\
Mean \pm SD & $94.0 \pm 23.8$ & $65.7 \pm 15.2$ & $52.5 \pm 10.1$ & $66.3 \pm 14.6$ & $61.0 \pm 48.8$ \\
\hline
\end{tabular}

The average level of respondents' general knowledge is good enough categorized with an index of 65.7. This was evidenced by almost all respondents already knew the extension of FP.

\section{Perception of Risks}

Table 2 shows that in overall 7 out of 10 respondents' perceive that contraception for birth control has little risk for health or nonhealth aspects and only a few respondents thought that FP has many risks for health and non-health aspects.

The index also shows that average index which is 52.5 shows low perceive about contraception for birth control risks to health and non-health aspects.

Table 3 Compatibility test results for the whole model

\begin{tabular}{|c|c|c|c|c|}
\hline No & $\begin{array}{l}\text { Goodness-of- } \\
\text { Fit }\end{array}$ & $\begin{array}{l}\text { Cut-off- } \\
\text { Values }\end{array}$ & Results & Annotation \\
\hline 1. & CMIN/DF & $\begin{array}{c}1 \leq \\
\text { CMIN/DF } \\
\leq 3\end{array}$ & 1.325 & Good fit \\
\hline 2. & $\begin{array}{l}\text { Root Mean } \\
\text { Square } \\
\text { Residual } \\
\text { (RMR) }\end{array}$ & $\leq 0.1$ & 0.010 & Good fit \\
\hline 3. & $\begin{array}{l}\text { Goodness Of } \\
\text { Fit Index } \\
\text { (GFI) }\end{array}$ & $\geq 0.90$ & 0.946 & Good fit \\
\hline 4. & $\begin{array}{l}\text { Root Mean } \\
\text { Square Error } \\
\text { of } \\
\text { Approximation } \\
\text { (RMSEA) }\end{array}$ & $\leq 0.08$ & 0.040 & Good fit \\
\hline 5. & $\begin{array}{l}\text { Adjusted } \\
\text { Goodness Fit } \\
\text { Of Index } \\
\text { (AGFI) }\end{array}$ & $\geq 0.90$ & 0.919 & Good fit \\
\hline 6. & $\begin{array}{l}\text { Incremental } \\
\text { Fit Index (IFI) }\end{array}$ & $\geq 0.80$ & 0.897 & $\begin{array}{l}\text { Marginal } \\
\text { fit }\end{array}$ \\
\hline 7. & $\begin{array}{l}\text { Normed Fit } \\
\text { Index (NFI) }\end{array}$ & & 0.682 & \\
\hline 8. & $\begin{array}{l}\text { Comparative } \\
\text { Fit Index (CFI) }\end{array}$ & $\geq 0.80$ & 0.888 & $\begin{array}{l}\text { Marginal } \\
\text { fit }\end{array}$ \\
\hline
\end{tabular}

\section{Husband's Support}

This study discovered that the biggest proportion of respondents' perceptions of husband support is in medium category $(43.5 \%)$. This shows that the husband's role in using contraception for birth control is important, thus with the support of husband so the wife will be more comfortable to use contraception for birth control, can exchange opinions about FP, and the husband can take his wife for FP program. The average husband's support in this study was in the medium category with the score of 66.3 . This means that the husband understood that FP is a shared responsibility. However, the husband is still not involved in decisions making process to use contraception.

\section{Interest}

Anothe finding of this study (Table 2) also reported that 6 out of 10 samples were interested in using contraception for birth control. Other respondents $(39.0 \%)$ had no interest at all in using traditional contraception for birth control for various reasons. This proves that there are still 4 out of 10 respondents that are not interested even though they still have the opportunity to have children as reproductive age of women.

\section{Feasibility Test of the SEM}

Feasibility test of SEM model can be seen from CMIN / DF, RMR, GFI, RMSEA, AGFI, II, NFI, and $\mathrm{CFI}$ as it is shown in Table 3 . The value of the aspects of the feasibility's criteria has included the category of the goodness of fit and marginal fit which means that the overall model of this study is declared feasible. 


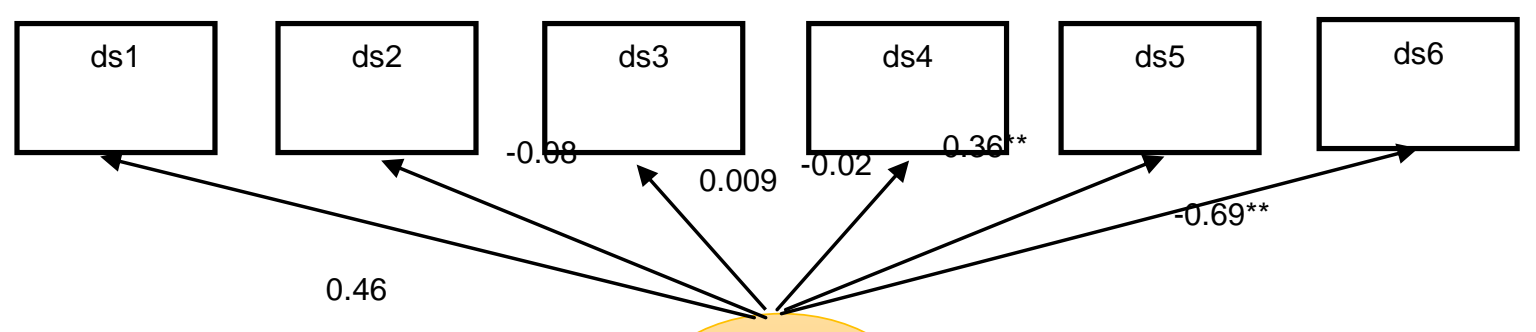

DS

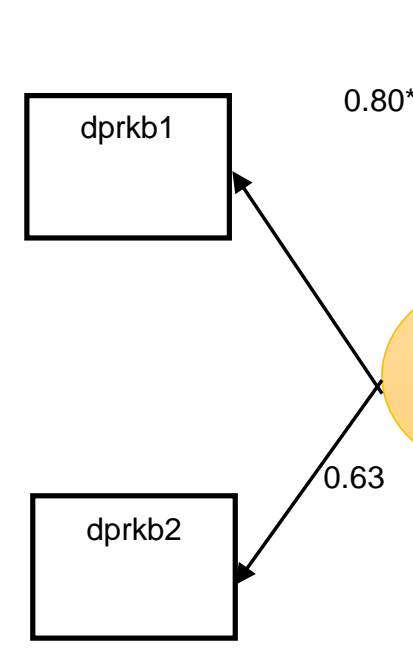

$-0.26$

PRKB

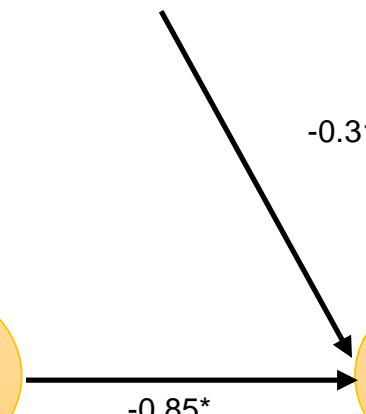

$-0.31$

$-0.85^{*}$
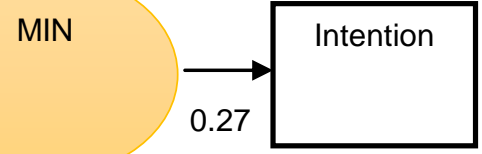

63

akses

AKSES

$0.97^{*}$

Note: * Significant at $\mathrm{p}<0.05$; * Significant at $\mathrm{p}<0.01$,

Exogenous variables: ACCESS: Access information; PENG: Knowledge, DS: Husband's support.

Endogenous variables: CRP: Perception of contraception for birth control risk; MIN: Interest.

Figure 1 The result of the SEM model 
Table 4 Hypothesis testing of SEM model

\begin{tabular}{|c|c|c|}
\hline Line & $\begin{array}{c}\text { Line's } \\
\text { Coefficients } \\
\end{array}$ & Annotation \\
\hline 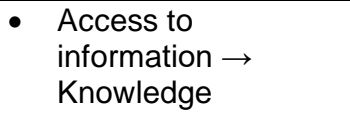 & $0.97^{*}$ & Accept H1 \\
\hline $\begin{array}{l}\text { - } \text { Access to } \\
\text { information } \rightarrow \\
\text { Perception of risk }\end{array}$ & -0.26 & $\begin{array}{l}\text { Rejected } \\
\mathrm{H} 2\end{array}$ \\
\hline $\begin{array}{ll}\text { - } & \text { Knowledge } \rightarrow \\
& \text { Perception of risk }\end{array}$ & 0.38 & $\begin{array}{l}\text { Rejected } \\
\mathrm{H} 3\end{array}$ \\
\hline $\begin{array}{l}\text { - Knowledge } \rightarrow \\
\text { Interest }\end{array}$ & -0.25 & $\begin{array}{l}\text { Rejected } \\
\mathrm{H} 4\end{array}$ \\
\hline $\begin{array}{l}\text { - Perception of risk } \rightarrow \\
\text { Interest }\end{array}$ & $-0.85^{*}$ & Accept H5 \\
\hline $\begin{array}{l}\text { - Husband's support } \\
\rightarrow \text { Interest }\end{array}$ & -0.31 & $\begin{array}{l}\text { Rejected } \\
\mathrm{H} 6\end{array}$ \\
\hline
\end{tabular}

Based on the model proposed (Figure 1), the hypotheses of $\mathrm{H} 1$ to $\mathrm{H} 6$ were tested. Examining path coefficients in structural equation models did the tests. If the $p$-value $\leq$ 0.05 with $t$-count value $\geq 1.96$ then the influence of certain variables be included in the significant category, but if the $p$-value $\geq 0.05$ with $\mathrm{t}$-count value $\leq 1.96$ then the influence of individual variables belong to the nonsignificant category.

Based on the SEM analysis as it is shown in Table 4, out of the six hypotheses only two were stated to have a significant effect, while the other four hypotheses had no significant effect. The variable that had a significant positive effect was the influence of access to information on interest in using contraception and the variable that had a significant negative effect was the perception of risk was interest in using contraception.

\section{DISCUSSION}

Based on the analysis of the SEM model presented, this study discovered that the information access had a significant positive effect on knowledge because the $p$-value is smaller than 0.05 , hence the first hypothesis was accepted. These were alleged because the respondents' general knowledge of contraception for birth control and FP program was high, indicated by the number of respondents who knew the purpose of using family planning and knowing birth distance. Although their knowledge of contraception equipment was still low, it was shown by many respondents who stated that they did not know about tubectomy birth control, combined birth control pills were prohibited for mothers over 35 years of age and heavy smokers, and injection should not be used on mothers who are breastfeeding for less than 6 weeks.
This study found that respondents already had a good access to information about contraception for birth control and FP program and a good enough knowledge about contraception for birth control and FP program. This finding is similar to previous research which concludes that consumers with good access to information have good knowledge and awareness (Puspitasari, 2010).

Another finding revealed thet access to information about contraception for birth control and FP program did not significantly influence perceptions of contraception for birth control risk, therefore the second hypothesis in the model was rejected. Previous studies found that perceptions which is formed based on experience will have a stronger effect on the formation of risk perceptions compared to information access (Wahlberg, 2000). Other studies also mentioned that the availability of information has no relation with the respondent's risk perception (Lestari \& Iramani, 2013), and information search behavior has no relation with perceived risk (Koklic, 2011).

Moreover, this study also found that knowledge of respondents about contraception for birth control and FP program had no significant effect on perceptions of contraception for birth control risk (the $p$-value was greater than 0.05 ) hence the third hypothesis in the model was rejected. These result is in line with the previous research that found knowledge of contraception is unrelated to risk perception (Putri \& Simanjuntak, 2013). Knowledge of the respondents about contraception for birth control and FP program in this study was categorized as quite well while the risk perception is low.

This study also found that kknowledge of respondents about contraception for birth control and FP program did not have a significant effect on interest in using contraception, therefore so hypothesis in the model was rejected. On the contrary, the general research states that knowledge and attitudes have significant impact on reducing unmet need (Malwenna, Jayawardana \& Balasuriya, 2012). Other studies also demonstrated that there is a relation between knowledge of the wife and the interest of the group that needs to contraception (Wahab, Fitriangga, \& Handini, 2014). Knowledge in this study was categorized as good, while interest in this study was categorized as moderate. Even though they know about contraception for 
birth control, they are not necessarily interested in using it.

The results showed that risk perception variables had a significant adverse effect on interest to use contraception, hence hypothesis in the model was accepted. This is in line with research that suggested perceptions of contraception users that service quality contributes significantly to increasing interest and participation in FP program (Sudarti \& Prasetyaningtyas, 2011). The previous studies suggest that one of the reasons for the unmet need group is not the risk obout contraception but the presence of risk perceptions from pregnancy (Bhattathiry \& Ethirajan, 2016).

Other studies also revealed that risk perceptions in contraception using was directly influence the need to use contraception for unmet need group (Thohirun et al., 2015). In this study, respondents assumed that contraception had little risk for health or nonhealth aspects. Six out of ten respondents had the desire to use contraception. This shows that the lower the perceived risk, the higher the interest in using contraception; and vice versa, the high the perceived risk will reduce their interest in using contraception for borth control.

However, the husband's support did not significantly influence interest in using contraception. Thus, hypothesis in the model was rejected. This is in contrast with research that showed husband's support turned out to be the influence of the unmet need (Nanlohy, 2017). Other studies were also contradictive which suggested that the husband's support had a significant relationship with the incidence of unmet need in using contraception (Wahab, Fitriangga, \& Handini, 2014) and husband support is the most influential factor in unmet need (Sophia, Anwar, \& Lestari, 2016).

Based on the perceptions of the respondents, the husband is sufficiently supportive for using contraception and involved in FP program which is means that the husband assumed that FP is a shared responsibility. However, they still not be involved in the decision making. The respondents' interest in using contraception was acceptable, as many as 6 out of 10 respondents had the desire to use contraception. This shows that the husband has not fully provided support in using contraception though it does not affect the increase in respondents' interest in using contraception.

\section{Research Implications for Government Policy}

Based on the results of this study, the respondents' knowledge about contraception for birth control and FP program in general is good. However, respondents' knowledge of contraception equipment, contraception procedures, and the impact of contraception using are lacking. This is indicated by the fact that there are still people who do not have much information about regarding some contraception devices such as spiral, condoms, tubectomy, and injection are not allowed for patients who have a history of breast cancer, while mothers should not use combination pills over 35 years of age and heavy smokers.

Therefore, this research suggests to provide information from various sources of information, both conducted massively through public service advertisements and personally through midwives and cadres. Face to face consultation can be done to improve the understanding of family planning and might reduce risk perceptions about modern contraception methods (implants and spiral) and it could also reduce negative rumors about the impact of contraception using. For personal education, a visual aid tool is needed to support the successful delivery of messages effectively.

Information that is received by respondents in this study was done mostly through television and carried out by midwives or nurses. The implication of this research on government is to provide more information about the types of family planning, not just birth control pills and injections. For example, advertisements made on television. Midwives and nurses also need to invite and convey a lot of information to the public about the types of contraception devices that are still rarely heard by the public.

Based on the perceptions of the respondents, the husband is sufficiently supportive for family planning, which means that the husband has assumed that family planning is a shared responsibility but the husband is still not involved in the decision making the process. The implication that needs to do is to include the husband for involvement in the decision to use contraception. Health education campaigns aimed explicitly at husbands are needed to increase men's confidence and attitudes. Additionally improving accessibility, affordability, availability, accommodation, and acceptability of family planning services will 
make it more attractive for male partners (Babalola, Vondrasek, Brown, Traore, 2001).

In addition, there is a need of strengthening for wives such as to participate in communication, information, and education service (Komunikasi, Informasi, dan Edukasil KIE activities for FP services in order to increase their knowledge, improve their attitudes and provide practices of FP program; to increase understanding of family planning tools; to foster the sustainability of the participants, and to ensure the continuity of the FP program acceptance process. These activities must always be given to prospective participants and FP program participants and the unmet need group

Based on the results of the study, the respondents' interest in using contraception for birth control was good, however the figure still needs to be improved. The risk percentage affects the respondents' interest. Health risk perceptions have the biggest contribution to forming risk perception variables. The implication that needs to be done is to change people's negative perceptions of the side effects of modern contraception methods.

If it is expected that unmet need group to use modern and long-term contraceptives so education and guidance are certainly needed for them to increase revenue, guarantee suitable choices, guarantee the use of effective contraceptives, and ensure a longer continuity of family planning. The limitation of this study is that the sampling technique used nonprobability sampling or purposive method. This is because the data obtained is not as the field conditions. Thus it is not possible to do random sampling techniques. Non-probability sampling techniques could not be generalized by the illustrations of the conditions under study.

\section{CONCLUSION AND SUGGESTION}

Based on the results of the study, access to information about contraception for birth control and FP program received by respondents was good, and the information was widely accepted through television and midwives or nurses. The respondents' knowledge about contraception for birth control and FP program is included in the medium category, which means that people already know information about general knowledge about contraception for birth control and FP program, but their knowledge of contraception equipment is still low. In this study, respondents assumed that contraception had little risk for health or non-health. Husband respondents' support is good, husbands allow the wife to use contraception but are not involved in decisions making process. The respondents' interest in using contraception is quite good.

There are two hypotheses are accepted, namely access to information affects the knowledge $(\mathrm{H} 1)$ and the perception of risk affect the interest (H5). Nevertheles, there are four hypotheses were rejected, namely access to information affects the perception of risk $(\mathrm{H} 2)$, knowledge influences the perception of risk $(\mathrm{H} 3)$, knowledge affects the interest $(\mathrm{H} 4)$, and the husband support affects the interest $(\mathrm{H} 6)$.

The government's policy implications for reducing unmet need can be done by providing more information about the types of long-term contraception methods with their advantages, not only to include birth control pills and injections. Governemnt need to understand how to make efficient television advertisements. Midwives and nurses also need to be included and convey various information to the public face to face about the types of contraception method that is still rarely heard by the public.

In addition to government policies should encourage husbands to involve in decision making to use contraception Furthermore, husbands also have to be willing to use contraception device if the wife does not use it. Risk perceptions affect respondents' interest, meaning that the government can carry out activities that can change people's negative perceptions about the side effects of modern contraception method. One of the government programs, the Hope Family Program (PKH), is considered contrary to the FP program that is two children are enough. In the PKH program, more children will be assisted, and people will compete to have many children. Therefore, there needs to coordination program between government institutions or institutions related to family welfare.

In further research, it is expected to add other variables such as women's autonomy, as well as cultural values that may influence interest in contraception using in unmet need groups thus research on unmet need can be developed further. Also, it is necessary to further explore the perception of the husband's support for his wife's and his interest in using contraception. This research was only carried out in cities, and it would be better to cover rural and urban 
areas to gain a better description of unmet need performance.

\section{REFERENCES}

[BKKBN] National Population and Family Planning Board. (2017). Family Planning Program KKBPK Performance Indicator Survey. Jakarta, ID: BKKBN.

[BKKBN] National Population and Family Planning Board. (2008). National Family Planning Program Work Meeting 2008: Evaluation of the National Family Planning Program 2005-2007, Jakarta: BKKBN.

Babalola, S., Vondrasek, C., Brown, J., Traore, R. (2001). The impact of a regional family planning servis promotion initative in sub saharan africa:evidence from cameraoon. Inter Fam Palnn Perspect, 27(4), 186-193.

Bhattathiry, M.M,, \& Ethirajan, N. (2016). Unmet need for family planning among married woman of reproductive age group in urban Tamil Nadu. Journal of Family and Community Medicine, 21, 53-57.

Farahan, N. (2016). Description of the level of knowledge of the use of contraceptive devices in women of childbearing age and support of officers in the village of Bebandem, Karangasem, Bali. EJournal Medika, 5, 2303-1395.

Koklic, M.K. (2011). The consumer's perceived risk when buying a home: the role of subjective kno.wledge, perceived benefits of information research and information search behavior. E-journal of Economic Trends and Economic Policy, 21, 27-49.

Lekshmi, A.R., Ansuya., \& Manjula. (2014). A study to assess the factors influencing unmet need of family planning among married women in selected villages of udupi district, karnataka. Journal of Health Science, 4, 24-27.

Lestari, W., \& Iramani. (2013). Risk perception and trends of individual investor risks. Journal of Finance and Banking, 17(1), 78-88.

Malwenna, L.I., Jayawardana, P.L., \& Balasuriya, A. (2012). Effectiveness of a community based health educational intervention in reducing unmet need for modern methods of family planning among ever married reproductive age women in the Kalutara district Sri Langka. Journal of Collaborative Research on Internal Medicine \& Public Health, 4, 344-361.

Nanlohy, S. (2017). Determine the incidence of unmet need for family planning in Panakkukang Sub-district, Makassar City (Thesis). Universitas Hasanuddin, Makassar, Indonesia.

Pradhan, J.. \& Dwivedi, R. (2015). Why unmet need for family planning remains high in Bangladesh: a community level analysis. Journal of women's health care, 4, 1-7.

Puspitasari, C.D. (2010). Increased awareness of consumer rights of food products as an effort to realize consumer independence. Journal of Humanities Research, 15: 89-112.

Putri, A.M.L., \& Simanjuntak, M. (2013). Risk perception and intention to use contraception. Family and Consumer Science Journal, 6: 199-205.

Rasu, R.S., Rianon, N.J., Shahidullah, S.M., Faisel, A.J., \& Selwyn, B.J. (2011). Effect of educational level on knowledge and use of breast cancer screening practices in Bangladesh women. Journal of Health Care Women International, 32, 177-189.

Rehman, F., Javed, F., Nawaz, T., Ahmed, I., \& Hyder, S. (2014). Some insights in the historical perspective of hierarchy of effect model: a short review. Information Management and Business Review, 6, 301-308.

Sophia., Anwar, DA., \& Lestari, B.W. (2016). Husband's support towards unmet need of HIV positive-infected women of childbearing age. National Public Health Journal, 10, 156-161.

Sudarti, K., \& Prasetyaningtyas, P. (2011). Increased interest and decision to participate in FP acceptors. Journal of Management Dynamics, 2, 130-138.

Sunarti, E., Tati., Nuraini, A.S, Noorhaisma, R., Lembayung, D.P. (2005). Effect of economic pressure, social support, quality of marriage, parenting, and children's emotional intelligence on children's learning achievement. Nutrition and Family Media, 29 (1), 3440. 
Susilawati, F. (2013). An overview of the interests of childbearing women with the selection of implant contraceptive in the work area of the Meureudu health center, Meureudu District, Pidie Jaya District (Thesis). Institute of Health Science U'Budiyah, Banda Aceh, Indonesia.

Thohirun., Kuntoro., Sunarjo., \& Wibowo, A. (2015). Social factors and unmet need for family planning in district of Jember, Indonesia. Journal of Nursing and Health Science, 4, 19-25.

Wahab, R., Fitriangga, A., \& Handini, M. (2014). The relationship between factors of wife's knowledge and husband's support for the incidence of unmet need of FP in couples of childbearing age in the Central Siantan Sub-district of North Pontianak District.. Student Journal of PSPD FK Tanjungpura University, 1, 119.
Wahlberg, A.A., \& Sjoberg, L. (2000). Risk perception and the media. E-journal of Risk Research, 3, 31-50.

Wijaya, A., Aminah, T., \& Ristanto, R. (2013). Effect of 3-month injection KB on the increase in acceptor body weight at bps ny. s Lawang. Health Journal of Hesti Wira Sakti, 2, 163-167. 